Hydrol. Earth Syst. Sci., 16, 3127-3137, 2012

www.hydrol-earth-syst-sci.net/16/3127/2012/

doi:10.5194/hess-16-3127-2012

(C) Author(s) 2012. CC Attribution 3.0 License.

(c) (i)

\title{
On the sources of hydrological prediction uncertainty in the Amazon
}

\author{
R. C. D. Paiva ${ }^{1,2}$, W. Collischonn ${ }^{1}$, M. P. Bonnet ${ }^{2,4}$, and L. G. G. de Gonçalves ${ }^{3}$ \\ ${ }^{1}$ Instituto de Pesquisas Hidráulicas, Universidade Federal do Rio Grande do Sul, Porto Alegre, Brazil \\ ${ }^{2}$ Université Toulouse III Paul Sabatier, UMR5563, CNRS, OMP, GET,IRD, UT3, Toulouse, France \\ ${ }^{3}$ Centro de Previsão de Tempo e Estudos Climáticos CPTEC/INPE, Cachoeira Paulista, Brazil \\ ${ }^{4}$ International Joint Laboratory OCE, IRD, University of Brasilia, Brazil \\ Correspondence to: R. C. D. Paiva (rodrigocdpaiva@gmail.com)
}

Received: 5 March 2012 - Published in Hydrol. Earth Syst. Sci. Discuss.: 20 March 2012

Revised: 17 July 2012 - Accepted: 6 August 2012 - Published: 5 September 2012

\begin{abstract}
Recent extreme events in the Amazon River basin and the vulnerability of local population motivate the development of hydrological forecast systems using process based models for this region. In this direction, the knowledge of the source of errors in hydrological forecast systems may guide the choice on improving model structure, model forcings or developing data assimilation systems for estimation of initial model states. We evaluate the relative importance of hydrologic initial conditions and model meteorological forcings errors (precipitation) as sources of stream flow forecast uncertainty in the Amazon River basin. We used a hindcast approach that compares Ensemble Streamflow Prediction (ESP) and a reverse Ensemble Streamflow Prediction (reverse-ESP). Simulations were performed using the physically-based and distributed hydrological model MGB-IPH, comprising surface energy and water balance, soil water, river and floodplain hydrodynamics processes. The model was forced using TRMM 3B42 precipitation estimates. Results show that uncertainty on initial conditions plays an important role for discharge predictability, even for large lead times ( $\sim 1$ to 3 months) on main Amazonian Rivers. Initial conditions of surface waters state variables are the major source of hydrological forecast uncertainty, mainly in rivers with low slope and large floodplains. Initial conditions of groundwater state variables are important, mostly during low flow period and in the southeast part of the Amazon where lithology and the strong rainfall seasonality with a marked dry season may be the explaining factors. Analyses indicate that hydrological forecasts based on a hydrological model forced with historical meteorological data and optimal initial conditions may be feasible. Also, development of data assimilation methods is encouraged for this region.
\end{abstract}

\section{Introduction}

Recent extreme hydrological events have occurred in the past years in the Amazon River basin, such as the 2009 flood (Chen et al., 2010) and the 1996 (Tomasella et al., 2010), 2005 (Marengo et al., 2008; Zeng et al., 2008; Chen et al., 2009) and 2010 (Espinoza et al., 2011; Marengo et al., 2011) droughts. These extreme events caused several impacts on local population, since most settlements lie along the Amazon and its main tributaries where susceptibility to floods is large. Also, local population strongly depends on these rivers for transportation of people and goods, agriculture, generation of hydroelectricity, among other needs. The vulnerability to hydrological extremes could be reduced with information provided by Hydrological Forecast Systems.

Currently, the attempts for developing hydrological forecasts in the Amazon are all based on statistical methods. Uvo and Grahan (1998) and Uvo et al. (2000) developed seasonal water level and discharge forecasts (March-May period) for 6 river stream gauges in the Brazilian Amazon, including Belo Monte, Samuel and Balbina reservoirs sites and also Negro River at Manaus, based on rain gauge data, streamflow data and Pacific and Atlantic Ocean sea surface temperatures (SSTs) using a canonical correlation analysis in the first and an artificial neural network approach in the latter. The authors conclude that, in the Amazon, it is possible to forecast seasonal runoff one season in advance with a certain degree of accuracy using empirical models, SST and/or precipitation data, with correlation coefficient between observed and estimated discharges ranging from -0.38 to 0.74 in Uvo and Grahan (1998) and from 0.53 to 0.86 in Uvo et al. (2000). Schongart and Junk (2007) presented retrospective forecasts

Published by Copernicus Publications on behalf of the European Geosciences Union. 
of the maximum water level in Central Amazonia (Manaus) using El Niño - Southern Oscillation (ENSO) indices. Cappalaere et al. (1996) developed flood forecasts methods for Central Amazonia (Manaus) for lead times ranging from 10 to 60 days, using statistical-type modelling of the stage time series recorded at the main river gauges in the Brazilian Amazon basin.

However, hydrological forecast systems based on physically based hydrological models such as Wood et al. (2002), Collischonn et al. (2005) or Thielen et al. (2009) were not evaluated in the region, although hydrological modelling of the Amazon is being continually developed (e.g. Beighley et al., 2009; Decharme et al., 2008; Coe et al., 2007; Getirana et al., 2010; Paiva et al., 2011, 2012a, b; Trigg et al., 2009; Yamazaki et al., 2011; Guimberteau et al., 2012).

Prediction errors of the hydrological forecast systems arise from uncertainty on (i) model structure and parameters, (ii) atmospheric forcing such as precipitation and (iii) initial states (e.g. preceding soil moisture or volume of water stored in rivers and floodplains). The type of model forcings can range from simple climatology to an ensemble of historical meteorology (Day, 1985) or to more complex weather forecasts obtained from general or regional circulation models (e.g. Collischonn et al., 2005; Wood et al., 2002). In contrast, several data assimilation methods (Reichle, 2008; Liu and Gupta, 2007) can be employed to improve initial states estimates. Numerous hydrologic remote sensing products that can be assimilated have been developed recently, such as river water levels from nadir altimeters (Alsdorf et al., 2007; Santos da Silva et al., 2010), Terrestrial Water Storage from GRACE mission (Tapley et al., 2004a, b; Chen et al., 2009), soil moisture estimates from SMOS mission (Kerr et al., 2001), flooded inundation extent (Hess et al., 2003; Papa et al., 2010; Prigent et al., 2007), energy fluxes and evapotranspiration (e.g. Vinukollu et al., 2011) and in future flooded extent with water level from the SWOT mission (Durand et al., 2010). Therefore, the knowledge of the relative importance of each source of errors plays an important role on the hydrological predictability and also supports the choice of technique to be developed first: improving model structure, improving or looking for better model forcings, or developing data assimilation systems for better initial conditions estimates. In the later case, it is also important to evaluate what are the key state variables and what data to assimilate.

In this direction, Wood and Lettenmaier (2008) developed an approach to evaluate the relative importance of errors in hydrologic initial conditions and model meteorological forcings as sources of hydrologic uncertainty. Latter, Shukla and Lettenmaier (2011) and Shukla et al. (2011) applied this approach to evaluate seasonal forecasts of cumulative runoff and soil moisture in the United States and globally, respectively. We use a similar approach to evaluate the relative importance of hydrologic initial conditions and model meteorological forcings errors (precipitation) as sources of stream flow forecast uncertainty in the Amazon River basin. We assess (i) when each of these features are more important, i.e. at which lead time uncertainty arising from meteorological forcings errors becomes larger than from initial conditions errors and in which season; (ii) where, i.e. in which rivers; (iii) what are the key state variables contributing for uncertainty; and (iv) how it relates to Amazon River basin characteristics.

\section{Methods}

\subsection{Amazon River basin}

The Amazon River basin is the largest hydrological system of the world. It has an area of approximately 6 million $\mathrm{km}^{2}$, is responsible for $\sim 15 \%$ of fresh water released into the oceans and covers several South American countries, including Brazil, Bolivia, Peru, Colombia, Ecuador, Venezuela and Guiana (Fig. 1a). The Amazon consists of three main morphological units, namely the Andes, Amazon plain and the Guyanese and Brazilian shields (Fig. 1). Extensive seasonally flooded areas are found at the Amazon plains (Hess et al., 2003; Papa et al., 2010; Prigent et al., 2007) (see Fig. 1b), which store and release large amounts of water from the rivers and consequently attenuate and delay flood waves into several days or months (Paiva et al., 2012a, b).

Due to its size, the Amazon basin presents important spatial rainfall variability, as briefly described below following Espinoza et al. (2009a). Extremely rainy regions (more than $3000 \mathrm{~mm} \mathrm{yr}^{-1}$ ) are found in the northeast, in the Amazon delta exposed by the intertropical convergence zone (ITCZ) and in the southeast close to the South Atlantic Convergence Zone (SACZ). Rainfall decreases towards the southeast $\left(\sim 1500-2000 \mathrm{~mm} \mathrm{yr}^{-1}\right)$ and also in the Andes as a function of altitude (rainfall is generally less than $1000 \mathrm{~mm} \mathrm{yr}^{-1}$ in areas over $3000 \mathrm{~m}$ ). Concerning the seasonal cycle, contrasting rainfall regimes are found in northern and southern parts of the basin, with rainy season in June, July and August - JJA (in December, January and February - DJF) in the North (South). Seasonal variability, with defined wet and dry seasons, is present at southern and eastern parts of the basin, including Xingu, Tapajós, Madeira, Purus and Juruá river basins, but also at northern areas from Branco river basins (see Fig. 1a). Areas located at the Northwest (Maranon, Japurá and Negro river basins) exhibit weaker seasonal regime with large amounts of rainfall rates during the whole year (see Fig. 1a).

Spatial variability in the discharge regime is also observed in the Amazon, as described by Espinoza et al. (2009b) and as can be seen in Table 1. Rivers draining southern areas such as the Xingu, Tapajós, Madeira, Purus and Juruá (Fig. 1a) exhibit a southern tropical regime, with a maximum from March to May (MAM) and a minimum from August to October (Table 1). A northern tropical regime is found at Branco 


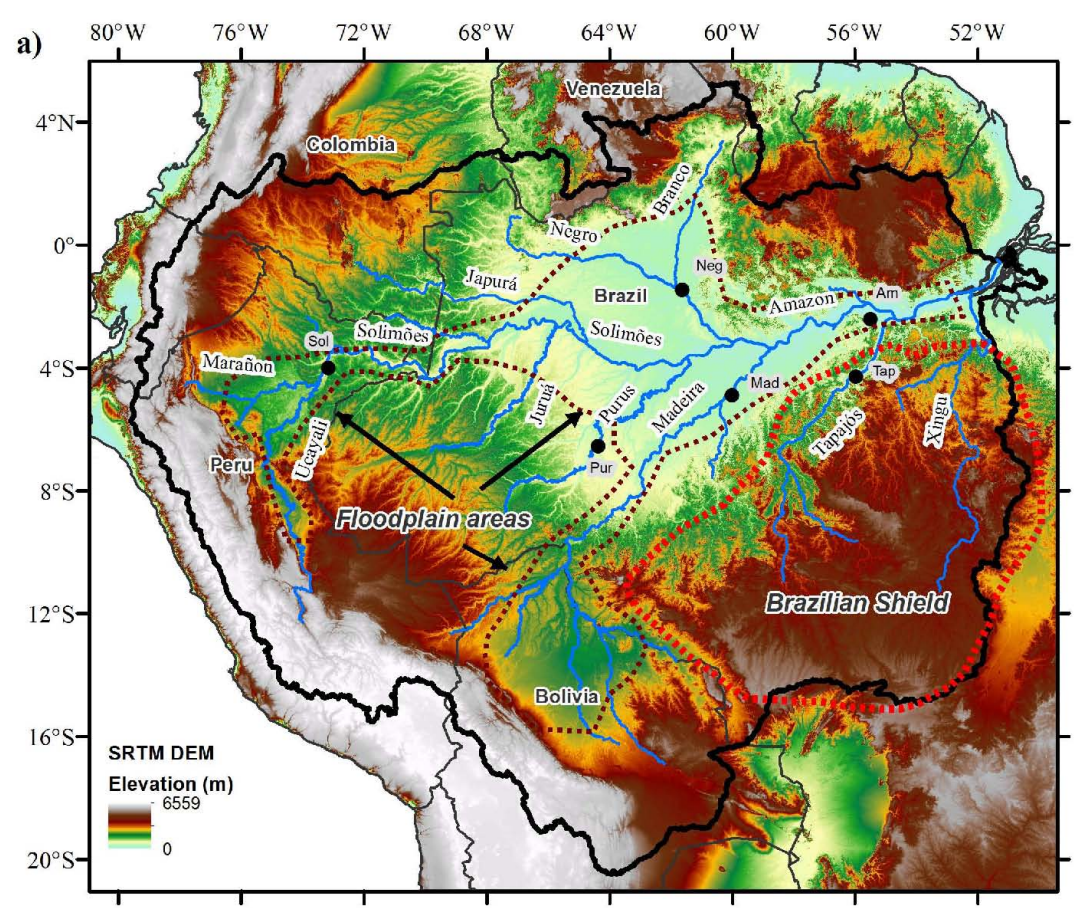

b)

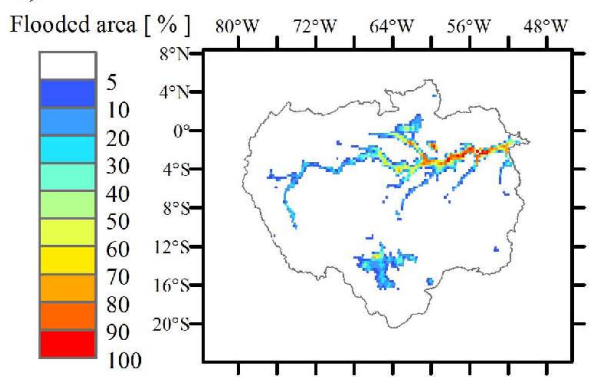

c)

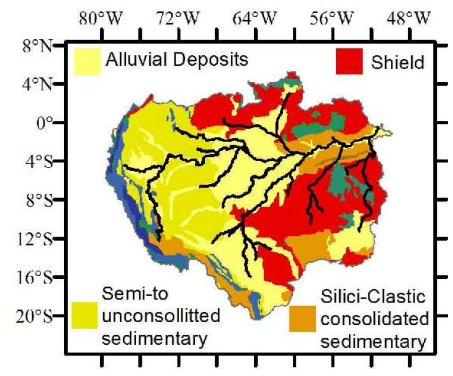

Fig. 1. (a) Amazon River basin with main tributaries, international limits, relief from SRTM DEM (Farr et al., 2007) and sites used in analyses (black circles), (b) mean flooded area (\%) derived from Papa et al. (2010) and (c) Lithological map derived from Durr et al. (2005).

River, where maximum flow occurs during June to August and minimum during December to March. Other rivers have weaker seasonal regimes (see $s_{\mathrm{VC}}$ values from Table 1), in some cases due to rainfall characteristics (e.g. Negro and Japura Rivers), and in the Solimões/Amazon main stem due to the contribution of lagged hydrographs from northern and southern areas. In the latter, high water occurs generally from May to July and low water from September to November but 1-3 months earlier in upper Solimões due to the flood wave travel time.

\subsection{ESP versus rev-ESP approach}

We used a hindcast approach developed by Wood and Lettenmaier (2008) that contrasts Ensemble Streamflow Prediction (ESP) and a reverse Ensemble Streamflow Prediction (reverse-ESP) (see Fig. 2). This approach uses ensemble model runs from a large scale distributed and process based hydrological model to evaluate the relative importance of errors in hydrologic initial conditions - ICs (e.g. soil moisture, groundwater storage, river discharge, floodplain storage, etc.), and model meteorological forcings - MFs (e.g. precipitation, surface air temperature, incoming solar radiation, etc.) as sources of stream flow forecast uncertainty.

In the ESP (Day, 1985), the model uses "perfect" initial conditions and runs forced by an ensemble of observed meteorological data from past years (see Fig. 2a). An estimate of "perfect" initial conditions is computed using a hydrological model driven by observed meteorological forcings up to the time of forecast (e.g. forecast starts with model states from 15 June 2000). Then, an ensemble forecast is obtained using observed meteorological data resampled from past years (e.g. meteorological data from 15 June to 25 September of years $1998,1999, \ldots, 2009)$. As a result, ESP shows a proxy of stream flow forecast uncertainty due to meteorological forcing errors (Wood and Schaake, 2008). In contrast, in reverse-ESP the model runs from an ensemble of simulated 
Table 1. Gauging stations from Fig. 1a with summary of discharge regime, MGB-IPH model skill and results.

\begin{tabular}{|c|c|c|c|c|c|c|c|c|c|}
\hline ID & Station & River & $\begin{array}{c}\text { Area } \\
\left(10^{3} \mathrm{~km}^{2}\right)\end{array}$ & $\begin{array}{c}Q_{\text {mean }} \\
\left(10^{3} \mathrm{~m}^{3} \mathrm{~s}^{-1}\right)\end{array}$ & $\underset{\left(10^{3} \mathrm{~m}^{3} \mathrm{~s}^{-1}\right)}{Q_{\min }}$ & $\underset{\left(10^{3} \mathrm{~m}^{3} \mathrm{~s}^{-1}\right)}{Q_{\max }}$ & $\begin{array}{c}s_{\mathrm{VC}} \\
\left(10^{3} \mathrm{~m}^{3} \mathrm{~s}^{-1}\right)\end{array}$ & $E_{\mathrm{NS}}$ & $\begin{array}{c}T \\
\text { (days) }\end{array}$ \\
\hline Sol 10075000 & Tamshiyacu & Upper Solimões & 724 & 29.5 & 14.5 (Sep) & 43.0 (May) & 0.35 & 0.74 & 37 \\
\hline Neg 14840000 & Moura & Negro & 648 & 31.4 & 10.7 (Jan) & 55.6 (Aug) & 0.59 & 0.65 & 56 \\
\hline Mad 15860000 & Faz. Vista Alegre & Madeira & 1320 & 26.9 & 6.5 (Sep) & 53.0 (Apr) & 0.65 & 0.92 & 53 \\
\hline Tap 17730000 & Itaituba & Tapajós & 461 & 11.2 & 3.5 (Sep) & 22.8 (Mar) & 0.64 & 0.87 & 41 \\
\hline Pur 13880000 & Canutama & Purus & 238 & 6.4 & 1.3 (Oct) & 12.8 (Apr) & 0.71 & 0.91 & 34 \\
\hline Am 17050001 & Obidos & Amazon & 4714 & 182.8 & 98.6 (Nov) & 250.1 (Jun) & 0.31 & 0.77 & 72 \\
\hline
\end{tabular}

$Q_{\text {mean }}$ - mean discharge, $Q_{\min }$ and $Q_{\max }$ - minimum and maximum monthly discharge derived from climatology with respective time of occurrence, $s_{\mathrm{VC}}-$ seasonal coefficient of variability computed as the ratio between the standard deviation of monthly discharges and $Q_{\text {mean }}, E_{\mathrm{NS}}-$ Nash and Suttcliffe index from simulated and observed discharges, $T$ values as described in Sects. 2.2 and 3.1 .

initial conditions from past years forced by a perfect forecast (see Fig. 2b). The initial conditions ensemble is obtained using the hydrological model forced by observed meteorological data resampled from past years during the spin-up period (up to the date of forecast) (e.g. model initial states from 15 June of years 1998, 1999, ..., 2009). Observed meteorological data from current year is used as perfect meteorological forecast (e.g. meteorological data form 15 June to 25 September 2000). Consequently, the reverse-ESP produces a proxy of stream flow forecast uncertainty due to model initial conditions errors. Model climatology (Fig. 2c), where either initial conditions and meteorological forcings are unknown, is used as a reference for comparing ESP and reverse-ESP model runs.

We use the ensemble spread (either for ESP, reverse-ESP and model climatology) as a measure of uncertainty in stream flow forecasts. For a given forecast $j$ starting at the time interval $t_{0}$ and at $\tau$ lead time, the ensemble spread $S$ is computed as the mean square deviation using simulated discharge $Q_{\text {sim }}$, as a reference:

$S(\tau, j)=\frac{1}{N} \sum_{i=1}^{N}\left(Q_{\mathrm{ens}_{i}}-Q_{\text {sim }}\right)^{2}$,

where $N$ is the ensemble size and $Q_{\text {ensi }}$ is stream flow from ensemble member $i$. The indexes $t$ and $\tau$ were omitted for simplicity. $S$ is computed for the ESP ( $\left.S_{\mathrm{ESP}}\right)$, reverse-ESP $\left(S_{\text {rev-ESP }}\right)$ and model climatology $\left(S_{\text {CLIM }}\right)$ ensembles. For a proper evaluation of stream flow uncertainty in different time periods, the model climatology is used as a reference and relative spreads are computed as $S_{\mathrm{ESP}}^{*}=S_{\mathrm{ESP}} / S_{\mathrm{CLIM}}$ and $S_{\text {rev-ESP }}^{*}=S_{\text {rev-ESP }} / S_{\text {CLIM }}$. Finally, results are averaged from all forecasts:

$S^{*}(\tau)=\frac{1}{M} \sum_{j=1}^{M} S^{*}(\tau, j)$,

where $M$ is the total number of forecasts performed in the test period and $S^{*}(\tau)$ is the relative ensemble spread as function of the lead time $\tau$.

The comparison of the spread of both sets of ensembles allows the evaluation of the relative importance of the ini- tial conditions and meteorological forcings on model predictability as functions of lead time (see Fig. 2d). Moreover, a proxy of the river "memory" $T$ can be obtained by verifying in which lead time $\tau$ the spread of ESP ensemble becomes larger than the reverse-ESP:

$T=\min (\tau) \mid S_{\text {rev-ESP }}^{*}(\tau)<S_{\mathrm{ESP}}^{*}(\tau)$.

\subsection{Hydrological model}

We used the MGB-IPH model (Collischonn et al., 2007; Paiva et al., 2011), which is a large scale, distributed and process-based hydrological model with a hydrodynamic module described in Paiva et al. (2011b). It simulates surface energy and water balance and also discharge, water level and flood inundation on a complex river network. We used results from a model application in the Amazon River basin (Fig. 1a) presented in Paiva et al. (2012b), as briefly described below. The model was forced using TRMM 3B42 precipitation estimates (Huffman et al., 2007), with spatial resolution of $0.25^{\circ} \times 0.25^{\circ}$ and daily time step for a period spanning $12 \mathrm{yr}$ (1998-2009) and meteorological data obtained from the CRU CL 2.0 dataset (New et al., 2002). Stream gauge data were provided by the Brazilian Agency for Water Resources (ANA), the Peruvian and Bolivian National Meteorology and Hydrology Services (both SENAMHI) and the HYBAM program (Hydrology, Biogeochemistry and Geodynamic of the Amazon Basin, http://www.ore-hybam.org/). The model parameters related to soil water budget were calibrated using discharge data from part of the stream gauges (47 stations). Then, the model was validated against discharge and water level data from stream gauge stations (111 and 69 sites, respectively), water levels derived from ENVISAT satellite altimetry data (Santos da Silva et al., 2010) (212 sites), Terrestrial Water Storage from GRACE mission (Tapley et al., 2004a, b) and flood inundations extent from Papa et al. (2010). Comparisons between simulations and observations showed relatively high Nash and Suttcliffe index $\left(E_{\mathrm{NS}}\right)$ values and a good model performance. $E_{\mathrm{NS}}$ values were larger than 0.6 in $\sim 70 \%$ of discharge gauges, and Table 1 shows $E_{\mathrm{NS}}$ ranging from 0.65 to 0.91 at the 6 discharge gauging stations analyzed in Sect. 3.1 
a)

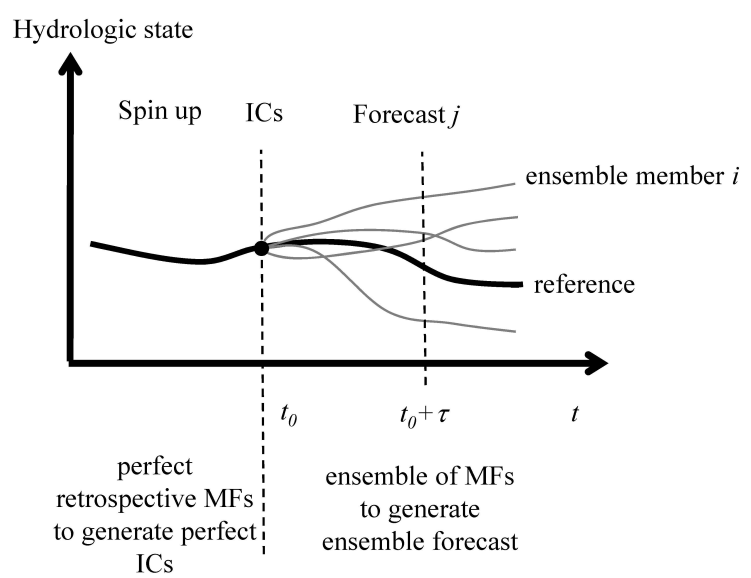

c)

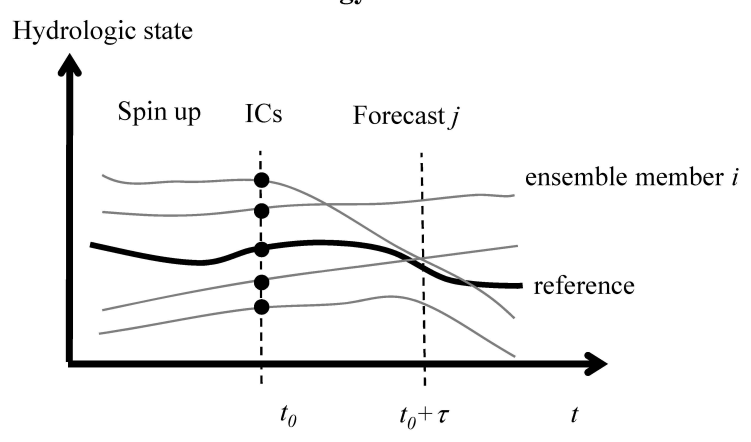

sequences of multi-year retrospective simulation using observed MFs

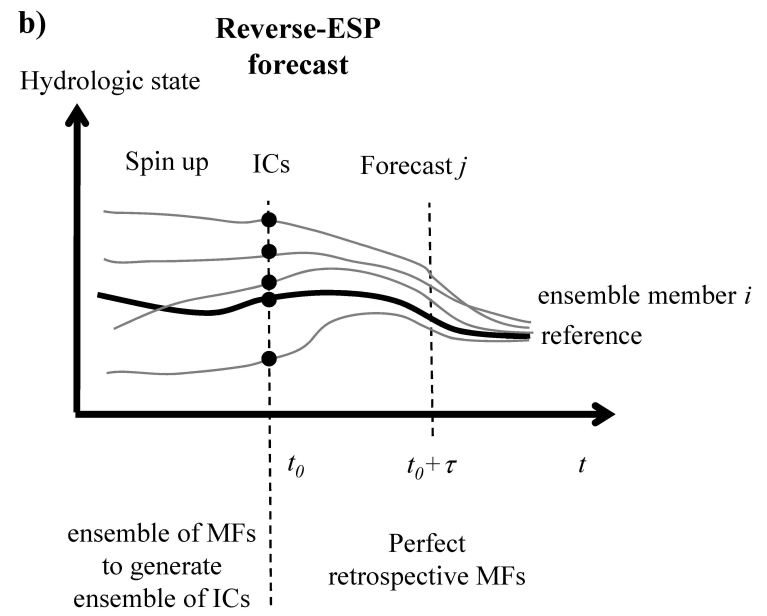

d)

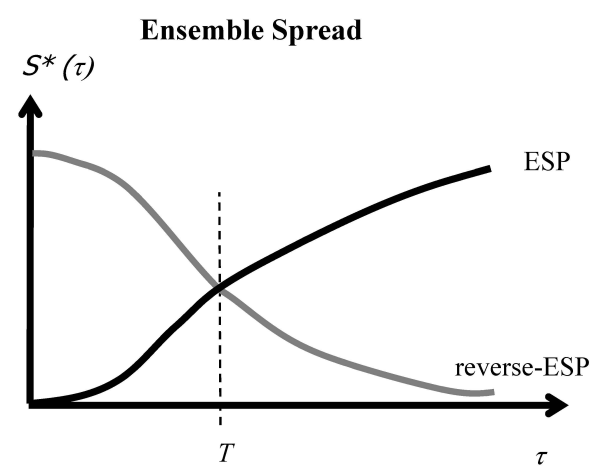

Fig. 2. Schematic representation of evolution of hydrologic states in spin-up and forecast for (a) ESP approach, (b) reverse-ESP approach, (c) climatology and (d) relative ensemble spread $S^{*}$ as function of lead time $\tau$. Modified from Wood and Lettenmaier (2008).

(Fig. 1a). Also, $E_{\mathrm{NS}}$ values were larger than 0.6 in $\sim 60 \%$ of the water level stations derived from satellite altimetry. Similarly, total Amazon flood extent and terrestrial water storage agreed with observations, with $E_{\mathrm{NS}}$ values of 0.71 and 0.93 , respectively.

\subsection{Model runs}

We performed 6 different model runs: (i) a retrospective simulation from which the ensemble of model climatology is derived and used as initial conditions for rev-ESP runs; (ii) an ESP run; (iii) a reverse-ESP run; and three restricted reverseESP runs, where (iv) in the first only surface waters state variables (river discharge and water level, floodplain storage and surface runoff) are considered; (v) in the second only soil moisture state variable is considered; and (vi) in the latter only groundwater state variables are considered. In all model runs, simulations used the 1998 to 2009 time period and ensembles have 12 members. ESP and reverse-ESP model runs generated 4 forecasts per year with up to 100 days lead time starting on 15 March, 15 June, 15 September and 15 December. Note that since we are using meteorological data obtained from the CRU CL 2.0 dataset (New et al., 2002), which provides only climatological values, uncertainty of meteorological variables different from precipitation is not accounted. We choose this simplification because MGB-IPH model using CRU CL 2.0 showed a reasonable performance when results were compared with observations (Paiva et al., 2012b), and most of Amazon discharge variability is due to precipitation variability.

\section{Results}

\subsection{Forecast uncertainty in main rivers}

We first explore forecast uncertainty results in 6 sites located in the main tributaries of Amazon River basin (see Fig. 2a and Table 1) using the $2003 / 2004$ hydrological year as an 
example (Fig. 3). Results show to be different for each site, although some characteristics are found in all of them.

In upper Solimões River, discharge starts to rise in September, and the spread of the ESP run rapidly surpasses the spread of the reverse-ESP run, showing that the importance of uncertainties in meteorological forcings is larger than from initial conditions (Fig. 3a). This situation changes in the other forecasts (at high water period in forecasts starting on 15 December and 15 March and in flow recession starting on 15 June) when the uncertainty in initial conditions appears to be more important than meteorological forcings. On average, the spread of the ESP ensemble $S_{\mathrm{ESP}}^{*}$ takes 37 days to surpass the spread of the reverse-ESP ensemble ( $T=37$ days in Fig. $3 b)$.

At the Negro River site, discharges rise during the MAM period, and differently from upper Solimões River, the forecast uncertainty due to initial conditions shows to be comparable, with uncertainty due to meteorological forcings even for large lead times (Fig. 3a). This characteristic is also present at high water (JJA) and flow recession periods (SON and DJF), and as a consequence, only after 56 days uncertainty in meteorological forcings becomes more important than in initial conditions (Fig. 3b).

At the rivers draining the southeast part of the Amazon with a southern tropical regime - namely Madeira, Purus and Tapajós Rivers - some common features are found. In the DJF period when discharge slowly starts to rise, and in the MAM period when it increases rapidly almost to flood peak, initial conditions uncertainties are important at the beginning of forecasts but the weight of meteorological forcings uncertainty becomes larger for smaller lead times. In contrast, at high water periods (JJA), flow recession and low water period (SON), the spread of reverse-ESP ensemble greatly surpasses the spread of the ESP ensemble, showing that initial conditions errors may have a large influence in flow forecasts uncertainty (Fig. 3a). $T$ values of Purus, Tapajós and Madeira Rivers showed to be different and approximately 34,41 and 53 days, respectively (Fig. 3b).

In the Amazon main stem, analysis show that the spread of reverse-ESP ensemble greatly surpass the spread of ESP ensemble in all periods of the year, including high water (MAM), low water (SON), rising (DJF) and falling (JJA) periods (Fig. 3a). Uncertainty in meteorological forcings becomes more important than in initial conditions only after 72 days (Fig. 3b).

Meteorological forcings seem to play an important role in forecast uncertainty at the rising water period, but this is not valid or not so strong in some of the largest rivers, such as Solimões, Negro and Amazon. Perhaps this is due to the flood travel times in these rivers and the contribution of lagged hydrographs from areas with different hydrological regimes (Sect. 2.1). In all rivers, the influence of initial conditions greatly surpasses MF's in high water period and mostly in flow recession and low water period. This characteristic in flow recession and low water period is very strong in rivers with southern tropical regime where rainfall seasonality is stronger and there is a very marked dry season (Espinoza et al., 2009a, b), as described in Sect. 2.1. In all Amazon large rivers, $T$ values can be considered very large, ranging from $\sim 30$ days at Purus Rivers to $\sim 70$ days in the Amazon River, showing that uncertainty on initial conditions may play an important role for hydrological predictability even for large lead times ( $\sim 2$ or 3 months).

\subsection{Spatial analysis}

We investigate the spatial distribution of $T$ values, indicating at which lead time uncertainty in meteorological forcings becomes more important than initial conditions for hydrological predictability, serving as a proxy of river "memory". According to Fig. 4a, large $T$ values are found at almost all Amazonian Rivers. $T$ values smaller than 10 days are found mostly in headwater and in the Andean region at west part of the Amazon where high river slopes are present (see also Fig. 1a). In most of the Amazon main tributaries, including Solimões, Juruá, Purus, Madeira, Tapajós, Xingu and Negro River, it is larger than 30 days and in Amazon main stem it is between 2 and 3 months. Results show that initial conditions may be the main source of discharge forecast uncertainty, even for large lead times ( $\sim 1$ to 3 months) in most Amazonian Rivers.

Results from restricted reverse-ESP runs (Fig. 4b, c and d) show larger $T$ values in analyzes considering only surface waters state variables (Fig. 4b). This suggests that initial conditions of surface waters state variables, which include river discharge and water levels, surface runoff and floodplain storage, are the major source of hydrological forecast uncertainty. This characteristic is present mostly in Solimões, Negro, Purus, Japurá, Madeira and Amazon Rivers that are located in low slope regions (Fig. 1a) with large seasonally inundated floodplains (see Fig. 1b), as described in Sect. 2.1. $T$ values in analyses using soil moisture restricted reverseESP run (Fig. 4c) are always less than 10 days, showing that initial conditions of soil moisture are not as important as initial conditions of other state variables. Finally, groundwater state variables showed to be important mostly in Tapajós and Xingu River basins located at southeast part of the Amazon.

The relative importance of meteorological forcings and initial conditions as sources of hydrological prediction uncertainty is variable according to the period of the year, as shown by seasonal analyses of $T$ values (Fig. 5). At rivers draining extensive floodplains, such as Solimões, Negro, Juruá, Madeira and Purus, $T$ values are always large, especially in high water and falling periods (MAM and JJA, see also Fig. 3). In these time periods, $T$ values larger than 90 days are found in the Amazon main stem.

The southeast part of the basin, including Xingu, Tapajos and Brazilian Madeira River basins, presents the most pronounced seasonal variation of $T$ values. At high water periods (DJF and MAM, see also Fig. 3), $T$ values range from 
a)
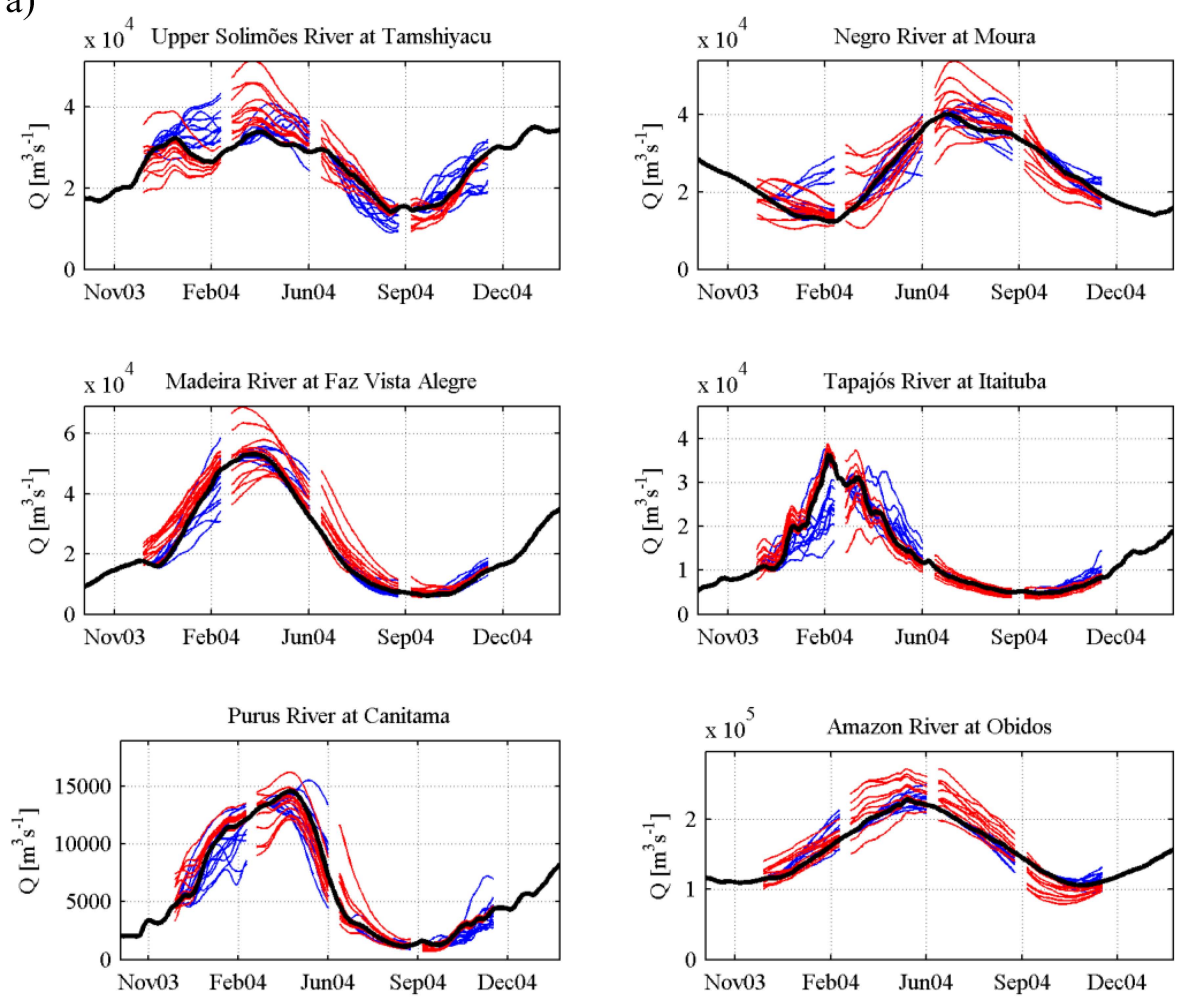

b)
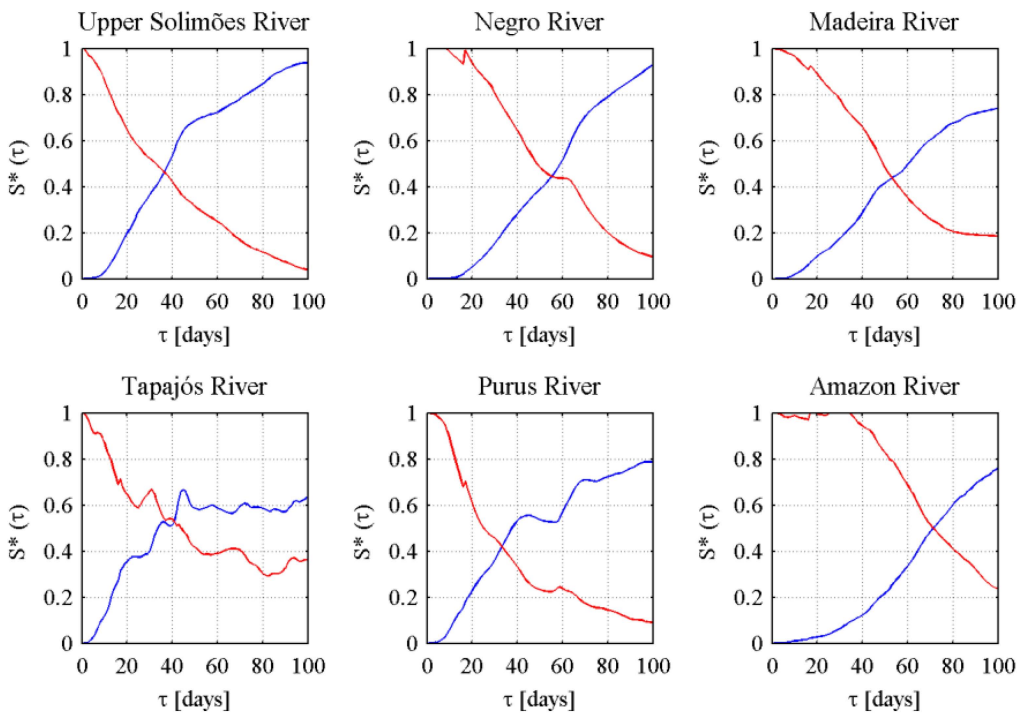

Fig. 3. Retrospective simulation (black), ESP (blue) and reverse-ESP (red) (a) discharge results and (b) relative ensemble spread $S^{*}(\tau)$ as function of the lead time $\tau$. Results are presented at upper Solimões (Sol), Negro (Neg), Madeira (Mad), Tapajós (Tap), Purus (Pur) and Amazon (Am) Rivers at sites shown in Fig. 1a.

10 to 30 days. But it increases a lot in low water period (JJA, SON), reaching values larger than 90 days. It shows that in this region, initial conditions are more important for hydrological prediction during low flows.

Results show that in rivers with extensive floodplains, initial conditions of surface waters state variables are the ma- jor source of prediction uncertainty and their importance increases during high water and falling period. This behavior may be related to the large flood wave travel times of these rivers, where these flood waves are delayed because floodplains store large volumes of water and release it slowly (Paiva et al., 2012a, b). 
(a)

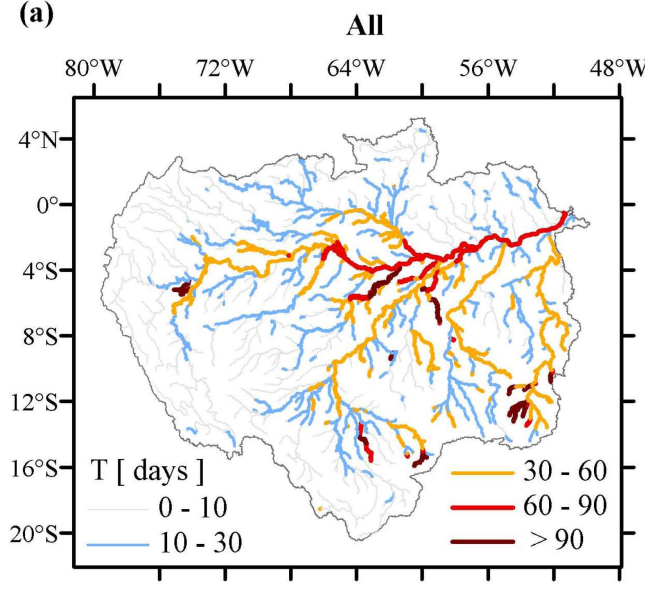

(c) (b)

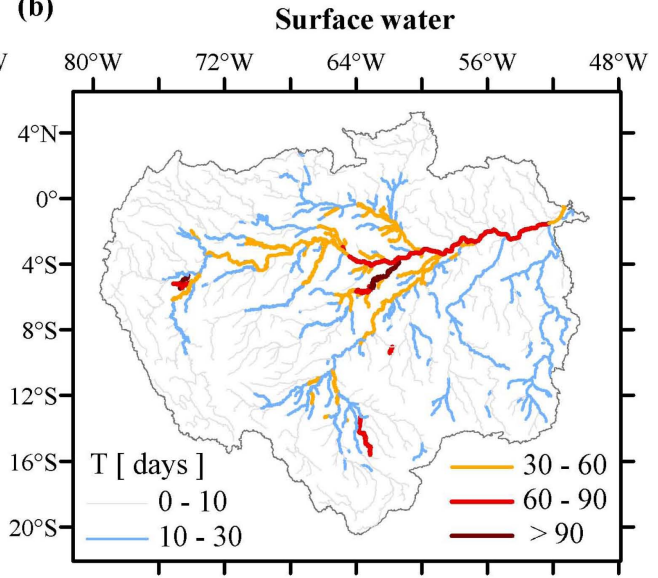

(d)
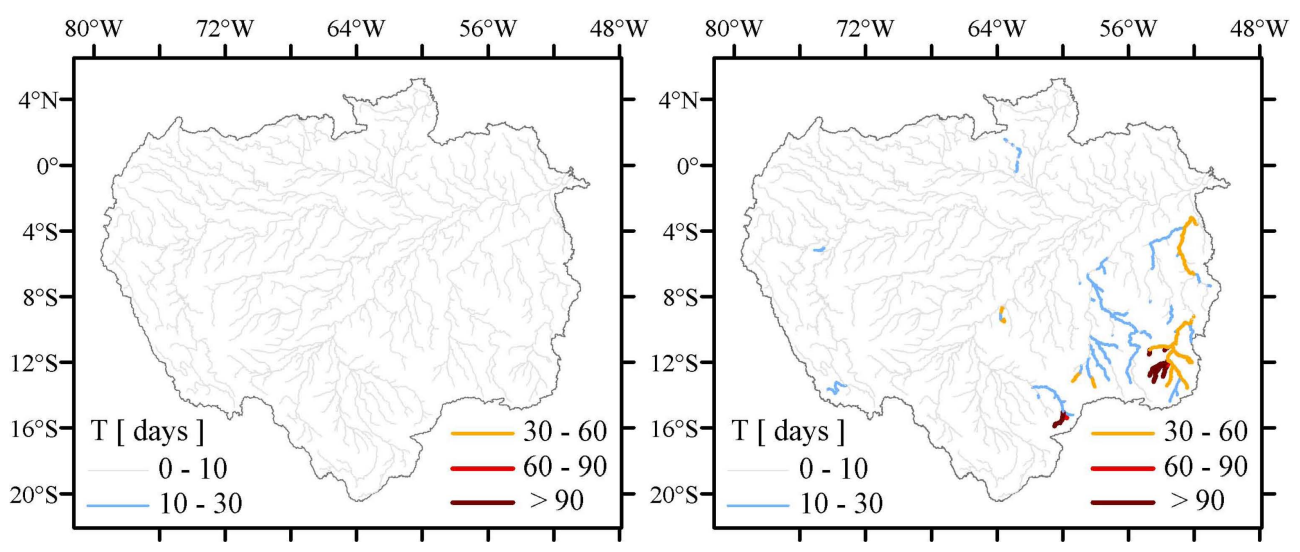

Fig. 4. Spatial distribution of $T$ values considering (a) all, (b) surface water, (c) soil moisture and (d) groundwater model states variables. Results are shown only in rivers reaches with upstream drainage area larger than $3000 \mathrm{~km}^{2}$.

On the other hand, at the southeast part of the basin (mainly at Tapajós and Xingu Rivers), initial conditions play an important role for prediction of low flows and groundwater state variables showed to be important. This region is the one that presents the strongest rainfall seasonality with a marked dry season, as discussed in Sect. 2.1 and by Espinoza et al. (2009a, b). It is also located mostly in the Brazilian Shield where lithological characteristics differ from the rest of the basin (Figs. 1a and 2c). So, a possible explanation for this behavior is that during low flows period, river discharge may be dominated by base flow, which is directly related to groundwater storage.

Finally, in a first comparison, our results disagree with Shukla et al. (2011), who applied the same methodology in a global analysis, presenting results that show that meteorological forcings uncertainties dominate the hydrological prediction uncertainty in the Amazon, even for shorter lead times. However, the results are not fully comparable since we evaluated river discharge while these authors studied cumulative runoff, which does not take into account flow routing throughout river, floodplain and groundwater reservoirs. Consequently, the water time traveling throughout these hydrological compartments and the associated memory to initial water storage in these reservoirs are not considered, which is probably the reason for the disagreement between results.

\section{Conclusions}

We investigate the importance of model initial conditions and meteorological forcings as sources of hydrological predictions uncertainty in the Amazon River basin. Our investigations show that in the Amazon River basin:

1. Uncertainty on initial conditions may play an important role for discharge forecasts even for large lead times ( $\sim 1$ to 3 months) on main Amazonian Rivers. This suggests that an Ensemble Streamflow Prediction approach (ESP), based on a hydrological model forced with historical meteorological data and using optimal initial conditions, may be feasible for hydrological forecasting even for large lead times ( $\sim 1$ to 3 months). Also, 
(a)

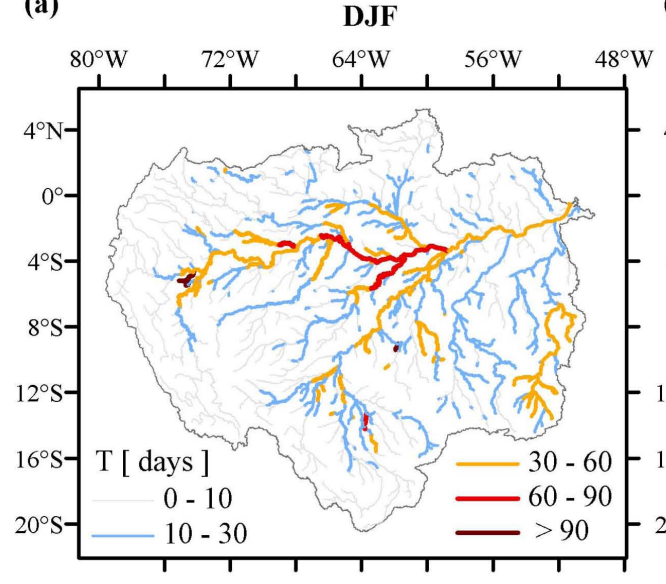

(c)

JJA (b)

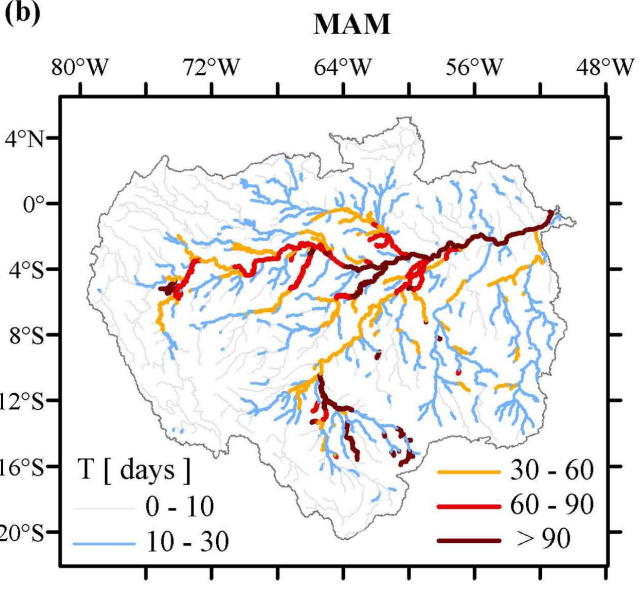

(d)
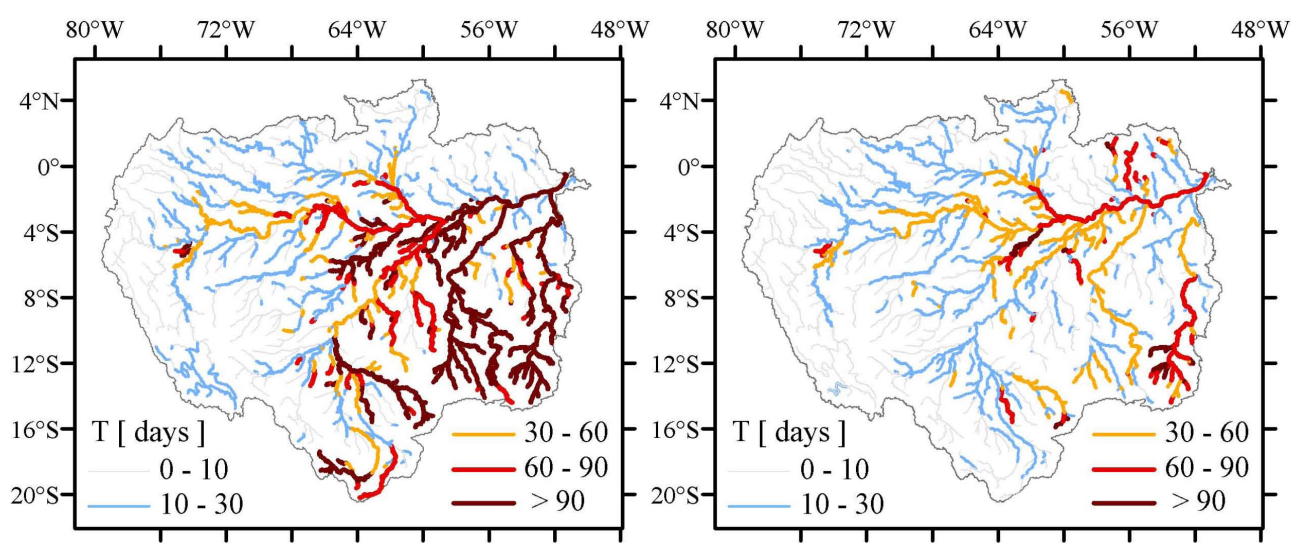

Fig. 5. Spatial distribution of $T$ values considering (a) DJF, (b) MAM, (c) JJA and (d) SON time periods. Results are shown only in rivers reaches with upstream drainage area larger than $3000 \mathrm{~km}^{2}$.

development of data assimilation methods is encouraged for reducing model initial conditions uncertainty.

2. Initial conditions of surface waters state variables are the major sources of hydrological forecast uncertainty, mainly in rivers with low slope and large floodplains, such as Solimões, Juruá, Japurá, Madeira, Negro and Amazon Rivers. Initial conditions of groundwater state variables are important mostly in the southeast part of the Amazon, in Tapajós as Xingu Rivers. Soil moisture is not as important as other state variables as a source of hydrological prediction uncertainty.

3. The relative importance of meteorological forcings and initial conditions as sources of hydrological prediction uncertainty is variable according to the period of the year.

4. At rivers draining extensive floodplains, initial conditions are more important in all time periods but especially in high water and falling periods (MAM and JJA). This can be related to the large flood wave travel times of these rivers, where these flood waves are delayed because floodplains store large volumes of water and release it slowly.

5. Meteorological forcings are more important in the beginning of the rainy season when hydrographs are rising, especially at the rivers draining southeast.

6. At the southeast part of the basin, mainly at Tapajós and Xingu Rivers, initial conditions play an important role for prediction of low flows (JJA, SON), and groundwater state variables showed to be important. A possible reason is that this region is the one that presents the strongest rainfall seasonality with a marked dry season. Lithology may be an explaining factor, since this region is located mostly over the Brazilian Shield.

Other kind of errors, such as in model structure and parameter, may also play an important role in hydrological predictability. However, we chose not to focus on it, supposing that the hydrological model is already calibrated with sufficient skill and that the main source of errors in a forecast situation would be in initial conditions and meteorological forcings. 
Results indicate that hydrological forecasts based on physically based and distributed hydrological models forced with past climate and optimal initial conditions may be feasible in the Amazon River basin and possibly in other world large rivers. It should also be mentioned the potentiality of recent remote sensing developments for providing past meteorological forcings (e.g. Tropical Rainfall Measurement Misson, Huffman et al., 2007, and others) and information to update model states, such as radar altimetry based water levels or discharge derived from previous (Alsdorf et al., 2007; Santos da Silva et al., 2010) or the future SWOT mission (Durand et al., 2010).

Acknowledgements. The authors are grateful for: the financial support from the Brazilian agencies FINEP and ANA ("Projeto de Integração e Cooperação Amazônica para a Modernização do Monitoramento Hidrológico" (ICA-MMH)) and CNPq ("Assimilação de Dados de monitoramento Espacial para a análise do regime hidrológico da Bacia Amazônica e a previsão de curto e médio prazos"); the TRMM data supplied by NASA and associated agencies; the global inundation extent dataset provided by Fabrice Papa; as well for the constructive comments from Sylvain Mangiarotti and Shraddhanand Shukla, and also from Wouter Buytaert, editor from HESS, Matthieu Guimberteau and the other anonymous reviewer.

Edited by: W. Buytaert

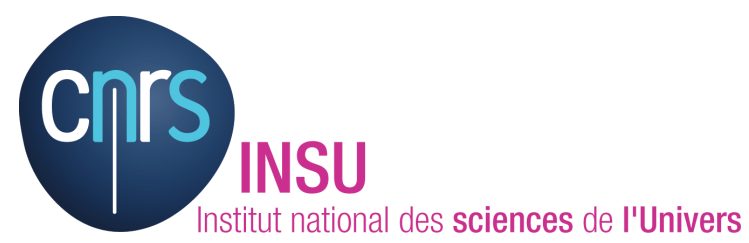

The publication of this article is financed by CNRS-INSU.

\section{References}

Alsdorf, D. E., Rodríguez, E., and Lettenmaier, D. P.: Measuring surface water from space, Rev. Geophys., 45, RG2002, doi:10.1029/2006RG000197, 2007.

Beighley, R. E., Eggert, K. G., Dunne, T., He, Y., Gummadi, V., and Verdin, K. L.: Simulating hydrologic and hydraulic processes throughout the Amazon River Basin, Hydrol. Process., 23, 12211235, 2009.

Cappelaere, B., Lubès-Niel, H., Berkhoff, C., Thépaut, H., Guyot, J. L., de Oliveira, E., and Rodrigues, M.: Prévisions des crues de l'Amazone. In: /. 'hydrologie tropicale: géoscience et outil pour le développement (Actes de la conférence de Paris, mai 1995), 355-366. IAHS Publ. no. 238, 1996.

Chen, J. L., Wilson, C. R., Tapley, B. D., Zang, Z. L., and Niu, G. Y.: The 2005 drought event in the Amazon River basin as measured by GRACE and estimated by climate models, J. Geophys. Res., 114, B05404, doi:10.1029/2008JB006056, 2009.
Chen, J. L., Wilson, C. R., and Tapley, B. D.: The 2009 exceptional Amazon flood and interannual terrestrial water storage change observed by GRACE, Water Resour. Res., 46, W12526, doi:10.1029/2010WR009383, 2010.

Coe, M. T., Costa, M. H., and Howard, E. A.: Simulating the surface waters of the Amazon River basin: Impacts of new river geomorphic and flow parameterizations, Hydrol. Process., 22, 25422553, 2007.

Collischonn, W., Haas, R., Andreolli, I., and Tucci, C. E. M.: Forecasting river Uruguay flow using rainfall forecasts from a regional weather-prediction model, J. Hydrol., 305, 87-98, 2005.

Collischonn, W., Allasia, D. G., Silva, B. C., and Tucci, C. E. M.: The MGB-IPH model for large-scale rainfall-runoff modeling, Hydrolog. Sci. J., 52, 878-895, 2007.

Day, G. N.: Extended streamflow forecasting using NWSRFS, J. Water Resour. Plann. Manage., 111, 157-170, 1985.

Decharme, B., Douville, H., Prigent, C., Papa, F., and Aires F.: A new river flooding scheme for global climate applications: Off-line evaluation over South America, J. Geophys. Res., 113, D11110, doi:10.1029/2007JD009376, 2008.

Durand, M., Fu, L. L., Lettenmaier, D. P., Alsdorf, D. E., Rodríguez, E., and Fernandez, D. E.: The surface water and ocean topography mission: Observing terrestrial surface water and oceanic submesoscale eddies, Proc. IEEE, 98, 766-779, 2010.

Durr, H. H., Meybeck, M., and Durr, S. H.: Lithologic composition of the Earth's continental surfaces derived from a new digital map emphasizing riverine material transfer, Global Biogeochem. Cy., 19, GB4S10, doi:10.1029/2005GB002515, 2005.

Espinoza, J. C., Ronchail, J., Guyot, J. L., Cocheneau, G., Filizola, N., Lavado, W., de Oliveira, E., Pombosa, R., and Vauchel, P.: Spatio - Temporal rainfall variability in the Amazon Basin Countries (Brazil, Peru, Bolivia, Colombia and Ecuador), Int. J. Climatol., 29, 1574-1594, 2009a.

Espinoza, J. C., Guyot, J. L, Ronchail, J., Cocheneau, G., Filizola, N., Fraizy, P., Labat, D., de Oliveira, E., Ordoñez, J. J., and Vauchel, P.: Contrasting regional discharge evolutions in the Amazon Basin, J. Hydrol., 375, 297-311, 2009b.

Espinoza, J. C., Ronchail, J., Guyot, J. L., Junquas, C., Vauchel, P., Lavado, W., Drapeau, G., and Pombosa, R.: Climate variability and extreme drought in the upper Solimões River (western Amazon Basin): Understanding the exceptional 2010 drought, Geophys. Res. Lett., 38, L13406, doi:10.1029/2011GL047862, 2011.

Farr, T. G., Caro, E., Crippen, R., Duren, R., Hensley, S., Kobrick, M., Paller, M., Rodriguez, E., Rosen, P., Roth, L., Seal, D., Shaffer, S., Shimada, J., Umland, J., Werner, M., Burbank, D., Oskin, M., and Alsdorf, D.: The shuttle radartopography mission, Rev. Geophys., 45, RG2004, doi:10.1029/2005RG000183, 2007.

Getirana, A. C. V., Bonnet, M.-P., Rotunno Filho, O. C., Collischonn, W., Guyot, J.-L., Seyler, F., and Mansur, W. J.: Hydrological modelling and water balance of the Negro River basin: evaluation based on in situ and spatial altimetry data, Hydrol. Process., 24, 3219-3236, 2010.

Guimberteau, M., Drapeau, G., Ronchail, J., Sultan, B., Polcher, J., Martinez, J.-M., Prigent, C., Guyot, J.-L., Cochonneau, G., Espinoza, J. C., Filizola, N., Fraizy, P., Lavado, W., De Oliveira, E., Pombosa, R., Noriega, L., and Vauchel, P.: Discharge simulation in the sub-basins of the Amazon using ORCHIDEE forced by new datasets, Hydrol. Earth Syst. Sci., 16, 911-935, 
doi:10.5194/hess-16-911-2012, 2012.

Hess, L. L., Melack, J. M., Novo, E. M. L. M., Barbosa, C. C. F., and Gastil, M.: Dual-season mapping of wetland inundation and vegetation for the central Amazon basin, Remote Sens. Environ., 87, 404-428, 2003.

Huffman, G., Adler, R., Bolvin, D., Gu, G., Nelkin, E., Bowman, K., Hong, Y., Stocker, E., and Wolff, D.: The TRMM Multisatellite Precipitation Analysis (TCMA): quasi-global, multiyear, combined-sensor precipitation estimates at fine scales, J. Hydromet., 8, 38-55, 2007.

Liu, Y. and Gupta, H. V.: Uncertainty in hydrologic modeling: Toward an integrated data assimilation framework, Water Resour. Res., 43, W07401, doi:10.1029/2006WR005756, 2007.

Kerr, Y., Waldteufel, P., Wigneron, J.-P., Martinuzzi, J.-M., Font, J., and Berger, M.: Soil moisture retrieval from space: The soil moisture and ocean salinity (SMOS) mission, IEEE T. Geosci. Remote Sens., 39, 1729-1736, 2001.

Marengo, J., Nobre, C., Tomasella, J., Oyama, M., de Oliveira, G., de Oliveira, R., Camargo, H., and Alves, L.: The drought in Amazonia in 2005, J. Climate, 21, 495-516, 2008.

Marengo, J. A., Tomasella, J., Alves, L. M., Soares, W. R., and Rodriguez, D. A.: The drought of 2010 in the context of historical droughts in the Amazon region, Geophys. Res. Lett., 38, L12703, doi:10.1029/2011GL047436, 2011.

New, M., Lister, D., Hulme, M., and Makin, I.: A high-resolution data set of surface climate over global land areas, Climate Res., 21, 1-25, 2002

Paiva, R. C. D., Collischonn, W., and Tucci, C. E. M.: Large scale hydrologic and hydrodynamic modeling using limited data and a GIS based approach, J. Hydrol., 406, 170-181, 2011.

Paiva, R. C. D., Collischonn, W., and Buarque, D. C.: Validation of a full hydrodynamic model for large scale hydrologic modelling in the Amazon, Hydrol. Process., in press, doi:10.1002/hyp.8425, 2012a.

Paiva, R. C. D., Collischonn, W., Bonnet, M. P., Buarque, D. C., Frappart, F., Calmant, S., and Mendes, C. B.: Large scale hydrologic and hydrodynamic modelling of the Amazon River basin, Water Resour. Res., in review, 2012b.

Papa, F., Prigent, C., Aires, F., Jimenez, C., Rossow, W. B., and Matthews, E.: Interannual variability of surface water extent at global scale, J. Geophys. Res., 115, D12111. doi:10.1029/2009JD012674, 2010.

Prigent, C., Papa, F., Aires, F., Rossow, W., and Matthews, E.: Global inundation dynamics inferred from multiple satellite observations, 1993-2000, J. Geophys. Res., 112, 1993-2000, 2007.

Reichle, R. H.: Data Assimilation methods in Earth sciences, Adv. Water Resour., 31, 1411-1418, 2008.

Santos da Silva, J., Calmant, S., Seyler, F., Rotunno Filho, O. C., Cochonneau, G., and Mansur, W. J.: Water levels in the Amazon basin derived from the ERS 2 and ENVISAT radar altimetry missions, Remote Sens. Environ., 114, 2160-2181, 2010.

Schongart, J. and Junk, W. J.: Forecasting the flood-pulse in Central Amazonia by ENSO-indices, J. Hydrol., 335, 124-132, 2007.

Shukla, S. and Lettenmaier, D. P.: Seasonal hydrologic prediction in the United States: understanding the role of initial hydrologic conditions and seasonal climate forecast skill, Hydrol. Earth Syst. Sci., 15, 3529-3538, doi:10.5194/hess-15-35292011, 2011.
Shukla, S., Sheffield, J., Wood, E. F., and Lettenmaier, D. P.: Relative contributions of initial hydrologic conditions and seasonal climate forecast skill to seasonal hydrologic prediction globally, Abstract H51N-05 presented at 2011 Fall Meeting, AGU, San Francisco, Calif., 5-9 December, 2011.

Tapley, B. D., Bettadpur, S., Watkins, M., and Reigber, C.: The gravity recovery and climate experiment: mission overview and early results, Geophys. Res. Lett., 31, L09607, doi:10.1029/2004GL019920, 2004a.

Tapley, B. D., Bettadpur, S., Ries, J. C., Thompson, P. F., and Watkins, M.: GRACE measurements of mass variability in the Earth system, Science, 305, 503-505, 2004 b.

Thielen, J., Bartholmes, J., Ramos, M.-H., and de Roo, A.: The European Flood Alert System - Part 1: Concept and development, Hydrol. Earth Syst. Sci., 13, 125-140, doi:10.5194/hess-13-1252009, 2009.

Tomasella, J., Borma, L. S., Marengo, J. A., Rodriguez, D. A., Cuartas, L. A. Nobre, C. A., and Prado, M. C. R.: The droughts of 1996-1997 and 2004-2005 in Amazonia: hydrological response in the river main-stem, Hydrol. Process., 25, 1228-1242, doi:10.1002/hyp.7889, 2010.

Trigg, M. A., Wilson, M. D., Bates, P. D., Horritt, M. S., Alsdorf, D. E., Forsberg, B. R., and Vega, M. C.: Amazon flood wave hydraulics, J. Hydrol., 374, 92-105, 2009.

Uvo, C. B. and Graham, N. E.: Seasonal runoff forecast for northern South America: A statistical model, Water Resour. Res., 34, 3515-3524, doi:10.1029/98WR02854, 1998.

Uvo, C. B., Tölle, U., and Berndtsson, R.: Forecasting discharge in Amazonia using artificial neural networks, Int. J. Climatol., 20, 1495-1507, doi:10.1002/1097-0088(200010)20:12<1495::AIDJOC549>3.0.CO;2-F, 2000.

Vinukollu, R. K., Wood, E. F., Ferguson, C. R., and Fisher, J. B.: Global Estimates of Evapotranspiration for Climate Studies using Multi-Sensor Remote Sensing Data: Evaluation of Three Process-Based Approaches, Remote Sens. Environ., 115, 801823, doi:10.1016/j.rse.2010.11.006, 2011

Wood, A. W. and Lettenmaier, D. P. An ensemble approach for attribution of hydrologic prediction uncertainty, Geophys. Res. Lett., 35, L14401, doi:10.1029/2008GL034648, 2008.

Wood, A. W. and Schaake J. C.: Correcting errors in streamflow forecast ensemble mean and spread, J. Hydrometeorol., 9, 132148, 2008.

Wood, A. W., Maurer, E., Kumar, A., and Lettenmaier, D. P.: Longrange experimental hydrologic forecasting for the eastern United States, J. Geophys. Res., 107, 4429, doi:10.1029/2001JD000659, 2002.

Yamazaki, D., Kanae, S., Kim, H., and Oki, T.: A physically based description of floodplain inundation dynamics in a global river routing model, Water Resour. Res., 47, W04501, doi:10.1029/2010WR009726, 2011.

Zeng, N., Yoon, J. H., Marengo, J. A., Subuamaniam, A., Nobre, C. A., Mariotti, A., and Neelin, J. D.: Causes and impact of the 2005 Amazon drought, Environ. Res. Lett., 3, 014002, doi:10.1088/1748-9326/3/1/014002, 2008. 